\title{
Improving The Ability of State Vocational High School Teachers in Creating Digital StoryTelling Media (DST) Using Sway Microsoft Tool Through Academic Supervision of Demonstration Technique
}

\author{
Siti Zakia \\ Department of Educational Administration on Supervision \\ Universitas Negeri Medan \\ Medan, Indonesia \\ nadzkiashei@gmail.com \\ H. Syaiful Sagala \\ Department of Educational Management \\ Universitas Negeri Medan \\ Medan, Indonesia \\ Paningkat Siburian \\ Department of Educational Management \\ Universitas Negeri Medan \\ Medan, Indonesia
}

\begin{abstract}
Media and digital technology are shaping contemporary approaches to teaching and learning. Teachers must be able to develop and utilize learning media in order to achieve learning outcomes. One of the efforts to help teachers improve the ability to create media is through academic supervision by demonstration technique. This study, therefore, aimed to describe the assembling process of academic supervision by using demonstration technique that can improve the teachers' ability of State Vocational High School in Tebing Tinggi to make digital storytelling media using sway and see the enhancement of teachers' ability in making DST media using sway. This study was a type of school action research which was designed to cycle process consists of four phases such as planning, action, observation, and reflection. Subjects in this study were English teachers from two State Vocational High School in Tebing Tinggi. The research instrument was observation sheet. The results showed that academic supervision of demonstration technique could improve teachers' ability in making DST media using sway microsoft tool in Vocational High School in Tebing Tinggi; and completeness of teachers' ability in making DST media using sway through academic supervision of demonstration technique completed classically.
\end{abstract}

Keywords - digital storytelling; sway; academic supervision of demonstration technique

\section{INTRODUCTION}

Education is the key to national development of any country, and in every educational system, the teachers constitute a very vital component. Despite the remarkable advancement in technology in all areas of teaching and learning process through the production of instructional materials such as television, computer projector of various kinds, the teacher is still an indispensably significant factor for motivating and imparting knowledge to the learners at each level of education. The extent to which teachers achieve this important role of imparting knowledge is contingent on their effective job performance [1].

From teacher pedagogic competence indicator that related to utilizing ICT (Information and Communication Technology) for the importance of learning is an important thing for teacher itself, especially in this era of globalization and technology. To achieve optimal results, all components in the learning process should not be ignored. One such component is the use of media in teaching, which is interconnected with other components in achieving teaching objectives. The use of media allows learners to learn better and can improve their performance, scientific attitude, learning outcomes and memory in accordance with the goals achieved. The use of media can help in learning because the media can help students learn a wide 
range of subject matter, which includes concepts, facts, principles, attitudes, and skills [2].

Various media, such as media, print and electronic information is needed to obtain a variety of sources of knowledge, which teachers should be up to date with developments in technology to support the learning process. Teachers must be good at utilizing technological progress as part of their creativity and innovation which can improve their ability in performing variation of media usage, thus ultimately influencing student achievement [3].

However, some realities that often occur in the school environment are still many teachers in learning more lectures and have not used instructional media. Sagala mentions that:

During this time schooling tends to show (1) Teachers more lectures; (2) Unused Media; (3) learning management tend to be classical and learning activities are less varied; (4) teacher demands on learning outcomes and low productivity; (5) there is no display of the work of the learners; (6) teachers and books as learning resources; (7) all learners are equal; (8) the assessment is only a test; (9) less and less challenging exercises and tasks; and (10) directional learning interactions [4].

Initial observation on student learning outcomes in State Vocational High School 2 (SMK Negeri 2) Tebing Tinggi grade $\mathrm{X}$ at network computer engineering class, showed that the result of midterms English exam for the 2016/2017 school year of 30 students only reaches 68.57 grade average with $63.33 \%$ classical completeness. To determine the cause of the problem, the researchers conducted a survey and interviews of teachers of English subjects in State Vocational High School 2 (SMK Negeri 2) Tebing Tinggi.

Based on the initial survey to English teachers at two State Vocational High Schools (SMK Negeri 2 and SMK Negeri 4) Tebing Tinggi revealed that the majority of teachers in these schools when teaching still use an approach that is teacher centered learning where teachers teach using lecture method, it is feared if teachers continue to use the approach and the method students tend to get bored quickly while following the learning process, whereas SMK Negeri 2 and SMK Negeri 4 Tebing Tinggi are accredited both already provide supporting facilities and infrastructure in complete learning process such as availability of electricity, LCD projector, computers and laptops as well as adequate internet facilities. Based on preliminary findings, this is because teachers still have difficulty in selecting appropriate media to help them teach the material in the classroom. Media on the market is mostly text book media and still a little media that uses the audio and visual aspects. Thus causing less optimal speaking skills (speaking) as well as listening skills (listening) owned learners.

The failure of teachers to implement technology in learning occurs because of the unpreparedness of teachers in the face of change, lack of skills, techniques and pedagogical knowledge to reflect the use of technology in the classroom. "Research has shown that the use of multimedia can aid in the comprehension and retention of student learning" [5]. If this condition is not immediately addressed then it can result in less effective learning in the classroom. The availability of internet facilities in schools is one component that can indirectly assist teachers.
Teachers easily access teaching materials, examples of application of concepts and other aspects that can be used in classroom learning.

One of the software that supports the use of learning media is Digital Storytelling (DST). In essence, DST is a combination of the art of communicating with some combination of digital graphics, text, record voice narration, video and music that provide information on a topic or experience with a specific time duration which is in digital format [6]. DST instructional media is one type of media that combine aspects of visualization of images and sound effects with a much more interesting. According Banaszewski, digital storytelling as "the practice of combining personal narrative with multimedia (images, audio and text) to produce a short autobiographical movie" [7].

This is supported by Robin states that "Digital Storytelling revolve around the idea of combining the art of telling stories with a variety of digital multimedia, such as image, audio, and video". Digital storytelling combines the art of telling stories with a mixture of digital media, including text, pictures, recorded audio narration, music and video. These multimedia elements are blended together using computer software, to tell a story that usually revolves around a specific theme or topic and often contains a particular point of view [8]. Digital storytelling holds unlimited possibilities as a teaching and learning method that engages students in critical thinking, development of cultural competency, and finding their voice within the educational environment [9].

Sway Microsoft Tool will help teachers to collect, format, and share ideas, stories and presentations on web-based interactive canvas that looks good virtually any screen. Teachers can create new Sway easy to add text, images, documents, video, charts, or other content type. By using Sway, teachers can present learning with more interest and invite students' curiosity. Students themselves can use the Sway app to present their tasks. By utilizing Sway application from microsoft, media creation DST will be more easy and innovative. Teachers can pour the teaching materials into the media according to learning indicators that will be developed. This reinforces DST to be applied as a learning media in the classroom.

Given the importance of the application of DST media using Sway in an effort to help teachers improve their ability in the learning process should be conducted academic supervision. Academic supervision is a series of activities to help teachers develop their ability to manage learning processes to achieve learning goals [10]. Academic supervision is an effort in guiding teachers to select and use strategies, methods and learning techniques for each subject. Academic supervision is one of the duties of supervisors. A supervisor has a set of roles and tasks that not only aim to oversee the course of education in schools well and directed, but also provide input, guidance and assistance to the principal and teachers in carrying out their schoolwork. There are two kinds of supervision techniques that can be implemented in developing the potential of teachers, namely individual techniques and group techniques. Individual techniques are supervisory techniques performed by the supervisor of a teacher or 
principal individually, while group supervision techniques are techniques of coaching a number of teachers by one or more supervisors [11].

Referring to the problems above, one technique that can be used in improving and improving the quality of teachers is a demonstration technique. The reasons for the selection of demonstration technique in an effort to improve the ability of teachers to create and use a web-based learning media among other things: (1) This technique is applied with the consideration that the supervisor identifies a specific skill / skill which they will introduce to the teacher as a trainee; (2) demonstration technique supervision is one of the proper techniques to train a special skill to a group of teachers, in this case is skills in making DST media use Sway; (3) demonstration technique can help teachers gain gradual understanding and skills with the help of supervisors; (4) the material discussed in this technique is almost entirely covers about things that can be practiced / demonstrated through demonstrations, such as a description of a computer or the internet / website.

Based on the description of the problem which has been described previously, the purpose of this study is to improve the ability of teachers at State Vocational High Schools (SMK Negeri) in Tebing Tinggi to make DST using sway microsoft tool through academic supervision of demonstration technique.

\section{METHOD}

The research was conducted in two State Vocational High Schools, namely SMK Negeri 2 and SMK Negeri 4 in Tebing Tinggi city, North Sumatera. The study was conducted from May to June 2017. The subjects in this study were 4 English teachers, each of which amounted to 2 English teachers at SMK Negeri 2 and SMK Negeri 4 Tebing Tinggi. The subjects of this study were obtained through a questionnaire distributed to teachers of English subjects on their desire to improve the learning process in innovative learning activities.

This research is a research study of school action (PTS). The action taken is the supervision of academic demonstration techniques with cooperation between researchers, supervisors, observers and teachers. The study was designed to process cycle consists of four phases namely planning activities (planning), action (action), observe (observation), and reflecting (reflection) as shown below:

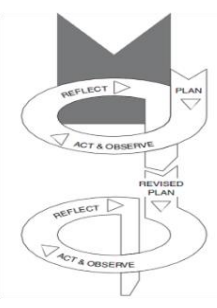

Fig. 1. Research Model Action Kemmis \& Mc. Taggart
The questionnaire as a preliminary observation aims to diagnose the experience of teachers to make learning media as well as the willingness of teachers to be observed. Observation sheet demonstrations implementation supervision techniques are used to: (1) observe the activities of teachers in training activities making DST media use sway; (2) assess the media display of DST using sway; (3) to observe the implementation of learning activities using DST media done by teachers ; (4) observing the action as a resource researchers conduct academic supervision of demonstration technique.

Data obtained from this research are: (a) data of the result of initial observation about making instructional media, (b) data of observation result of teacher activity in supervision activity with demonstration technique, (c) data of learning media assessment result made by teacher of trainee, (d) observed data of learning media simulation that has been created by the teacher of the trainee, (e) pre and post test result of the students related to the material presented in the media simulation in the learning activity in class, and (f) the observation data of the academic supervision of demonstration technique. Data were analyzed using technique.

Data analysis techniques in this study using a qualitative analysis approach, referring to the model of the flow (flow model) Miles and Huberman, which includes thee stages, namely: 1) reducing the data, the process of selecting information- relevant information from the beginning of data collection to the preparation of research reports; 2) Presentation of data, ie the compilation of narrative data from information

$$
\text { Average }=\frac{\text { Total score of acquisition }}{\text { Maximum score number }} \times 100
$$

obtained from data reduction for the material evaluated to determine the next action; 3) draw conclusions from the activities undertaken on the basis of data which is obtained [12].

\section{RESULTS}

Before carrying out academic supervision of demonstration technique, first do preliminary observations relating to the ability of teachers to use sway DST media. Preliminary observations indicate that teachers were still not able to make DST media, even in learning process, teachers were not using computer-based media/ internet website due to lack of mastering IT, lack of knowledge and understanding to make computer-based learning media/internet website. But the facilities in the school allow teachers for teaching using computers and internet websites. To that end, the teachers are willing to follow the training development of computer-based learning media and internet / website to make DST. Based on the data obtained in the initial conditions, there should be action on the first cycle to improve the ability of teachers make DST media use sway. The process is shown in this chart below 


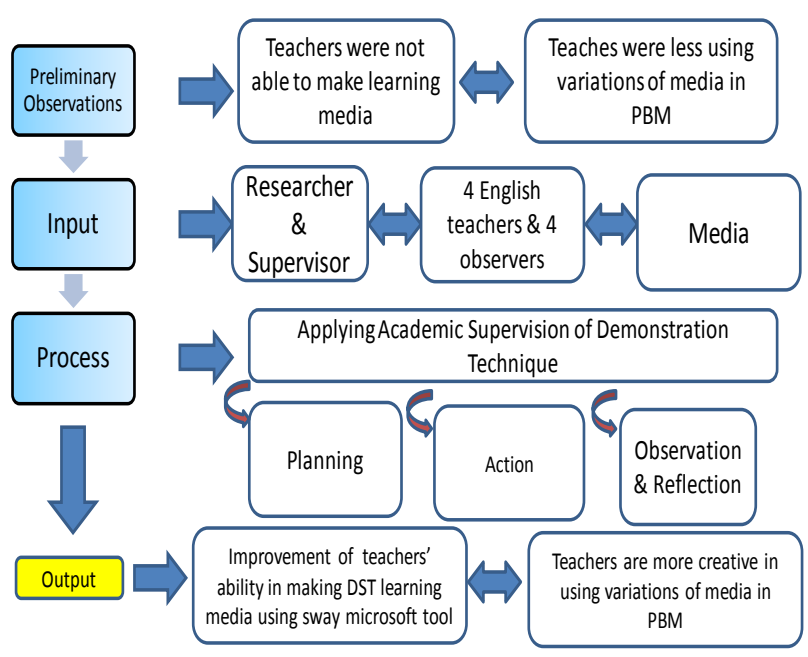

In detail the results of the analysis of the observation sheet of aspects of assessment ability of teachers to make instructional media DST using a sway in the first cycle can be seen in the table below which includes the aspects 1 media creation of DST using Sway, aspects 2 media display of DST using Sway, and aspects 3, observation of teachers during lessons using DST media.

Table I. Assesment All Aspects of Capability Teachers In Creating DST Using Sway In the first cycle

\begin{tabular}{|l|c|c|c|l|l|}
\hline \multirow{2}{*}{ Respondents } & \multicolumn{3}{|c|}{ VALUE OF ASPECT } & \multirow{2}{*}{ Avg. } & \multirow{2}{*}{ Category } \\
\cline { 2 - 5 } & Aspect & Aspect & Aspect & Value & \\
\hline 1 & $\mathbf{1}$ & $\mathbf{2}$ & $\mathbf{3}$ & & \\
\hline 2 & 81.04 & 80.83 & 80.00 & 80.62 & Good \\
\hline 3 & 56.25 & 62,50 & 72.92 & 63.89 & Less \\
\hline 4 & 60.42 & 65.00 & 72,32 & 65.91 & Enough \\
\hline Average & 66.67 & 69.17 & 76.57 & 70.81 & Enough \\
\hline
\end{tabular}

According to the table, the value of the average ability of teachers make DST media use sway in the first cycle was 70.31 with enough categories. Classical demands that at least get good category just reached $25 \%$ of the target $85 \%$ set. This suggests that the ability of teachers to make instructional media DST using sway still needs to be improved in the second cycle.

In a study in the field in the first cycle, to aspects of the ability of teachers to make DST media using a sway should become the concern that the participants are still less fluent in IT and still not master how to make use of DST use sway. It is seen from the data show that from 4 teachers, only one person who is able to operate sway, making DST media use sway and distribute DST to the public through the site docs.com.

Then to aspects of learning media display DST using sway, thing to note is teacher/ participants lacking creativity in creating IT-based media appearance, still less fluent in IT and the lack of teaching materials reference. It is seen from the data show that from 4 teachers, only 1 teacher who obtained either in component legibility criteria/ proporsonal letters, the use of images/ animations, sound use, the use of film / video, harmonizing colors, layout, andnavigation language.

Further to the simulation aspect of learning by applying DST media aided by sway, things to note that the teacher still not accustomed to applying DST media using sway in the classroom and DST learning media using sway made by teachers that has still not good. It is seen from the data show that from 4 teachers, only 1 teacher who obtained a good criterion in the components of teaching preparation, presentation / delivery of learning and teaching methods / learning implementation using sway DST .

Cycle II is an improvement from cycle I, the weaknesses encountered in cycle I are reflected and agreed upon the repair process and the improvement is implemented in cycle II. In detail the results of the observation sheet analysis of aspects of assessment ability of teachers to make instructional media of DST using sway in the second cycle can be seen in the table :

Table II. Assessment of All Aspects of Capability Teachers in Creating DST Using Sway On Cycle II

\begin{tabular}{|l|l|l|l|l|l|}
\hline \multirow{2}{*}{ Respondents } & \multicolumn{3}{|c|}{ VALUE OF ASPECT } & \multirow{2}{*}{$\begin{array}{c}\text { Avg. } \\
\text { Value }\end{array}$} & \multirow{2}{*}{ Category } \\
\cline { 2 - 5 } & $\begin{array}{c}\text { Aspect } \\
\mathbf{1}\end{array}$ & $\begin{array}{c}\text { Aspect } \\
\mathbf{2}\end{array}$ & $\begin{array}{c}\text { Aspect } \\
\mathbf{3}\end{array}$ & & \\
\hline \multirow{2}{*}{1} & 97.92 & 85.83 & 87.07 & 90.27 & $\begin{array}{l}\text { Very } \\
\text { good }\end{array}$ \\
\hline 2 & 87.50 & 80.00 & 83.64 & 83,71 & Good \\
\hline 3 & 87.50 & 81.67 & 83.84 & 84.34 & Good \\
\hline 4 & 93.75 & 80.83 & 85.66 & 86.75 & Good \\
\hline Average & 91.67 & 82.08 & 85.05 & 86.27 & Good \\
\hline
\end{tabular}

Based on Table II, the value of the average ability of teachers make DST media use sway on the second cycle is 86.27 with both categories. Classical completeness is at least obtain good category reaching $100 \%$ of the target $85 \%$ set. Increased teachers' ability make and use sway DST media from the first cycle to the second cycle can be seen in the following diagram:

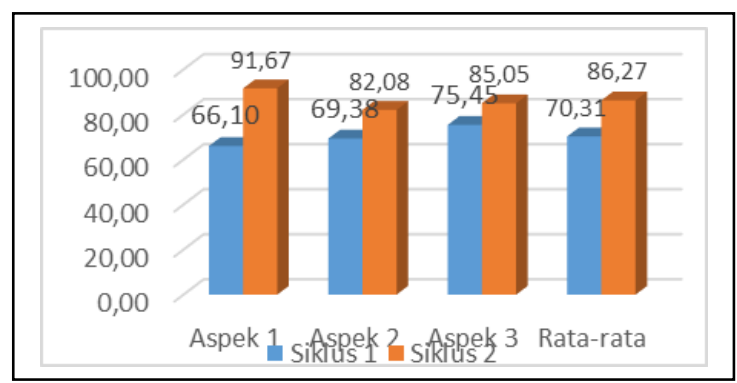

Fig II. Improvement of teachers' ability in creating DST using microsoft sway tool from the first cycle to the second cycle

Based on Fig II, it showed an increase in the average value teachers' ability in making DST using sway from the first cycle to the second cycle of 15.96. All aspects of teachers create DST using microsoft sway tool is also an increase from the first cycle to the second cycle. 
Based on the results of the study in the first and the second cycle is concluded that the academic supervision of demonstration technique can enhance teachers' ability to make DST using sway microsoft tool in State Vocational High Schools (SMK Negeri) Tebing Tinggi with classical completeness of $100 \%$.

\section{CONCLUSION}

Based on the results of analysis and research findings from the field, obtained some conclusions such as application of academic supervision of demonstration techniques can improve the ability of teachers in making digital strorytelling (DST) learning media using sway microsoft tool in State Vocational High School of Tebing Tinggi through some process. (1) an explanation of the concepts or skills to be taught; (2) demonstration of skills to participants / teachers; (3) discussion / question and answer during the implementation of activities; (4) guided training; and (5) self-training.

Improving the ability of teachers in making DST using sway microsoft tool in State Vocational High School of Tebing Tinggi through academic supervision of demonstration technique can be seen in the first cycle with an average score of 70.31 with sufficient criteria and increased in cycle II with an average value of 86.27 with good criteria. That is, an increase from cycle I to cycle II of 15.96 .

Completeness of the ability of teachers in making DST using sway microsoft tool through academic supervision techniques complete demonstration in class. This can be seen in the cycle I mastery of the ability of teachers in making DST using sway microsoft tool is $25 \%$ and increased in cycle II that is to $100 \%$ of the target completeness $85 \%$ classically.

\section{ACKNOWLEDGMENT}

This work is supported by Universitas Negeri Medan, subjects schools ie State Vocational High Schools (SMKN 2 and SMKN 4 Tebing Tinggi.

\section{REFERENCES}

[1] Ekpoh, Uduak Imo (Ph.D) and Eze, Grace Bassey, "Principals' Supervisory Techniques and Teachers' Job Performance in Secondary Schools in Ikom Education Zone, Cross River State, Nigeria," European Centre for Research Training and Development UK British Journal of Education, Vol.3, No.6, pp.31-40, June 2015. (references)

[2] Oemar Hamalik, Media Pendidikan. Bandung : Citra Aditya, 1989, pp .189 .

[3] Wina Sanjaya, Media Komunikasi Pembelajaran. Jakarta : Rineka Cipta, 2012.

[4] Syaiful Sagala, Kemampuan Profesional Guru dan Tenaga Kependidikan. Bandung : Alfabeta, 2011.

[5] Sanjaya Mishra \& Ramesh C. Sharma, Interactive Multimedia in Education and Training. United State of America : Idea Group Publishing, 2005, pp. 78.

[6] Dreon, O., Kerper, R., \& Landis, J, "Digital storytelling: A tool for teaching and learning in the YouTube generation". Middle School Journal, 42(5), 2011, pp. 4-9.

[7] T. Banaszewski, Digital storytelling: Supporting digital literacy in grades 4-12. Master's thesis, Georgia Institute of Technology, . 2005, unpublished.

[8] B.R. Robin, Digital Story Telling : A Powerful Technology Tool for the \21】^st Century Classroom. Theory Into Practice, The College of Education and Human Ecology, The Ochio State University, 2008, pp. 47:220-228.

[9] J. Burgess, "Hearing ordinary voices: Cultural studies, vernacula creativity and digital storytelling", Continuum: Journal of Media \& Cultural Studies, 2006, 20(2), 201214.

[10] Glickman, Supervision and Instructional Leadership (8th ed). Boston: Pearson Education, Inc, 2010.

[11] Nana Sudjana, Supervisi Pendidikan : Konsep dan Aplikasinya bagi Pengawas Sekolah. Bekasi : Binamitra-Publishing, 2011

[12] Sugiyono, Metode Penelitian Kuantitatif Kualitatif \& RND. Bandung : Alfabeta, 2010, pp. 246-252 